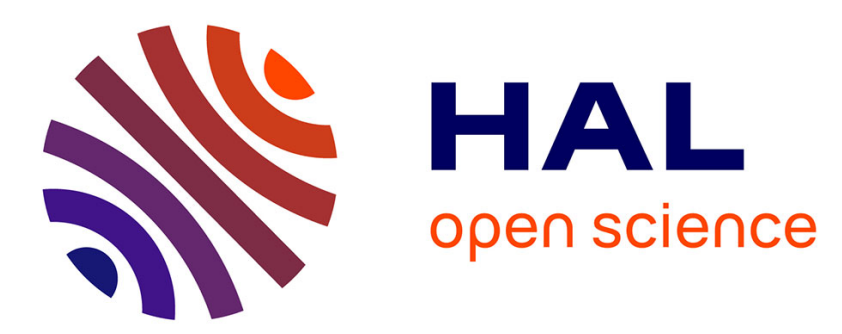

\title{
Production of all-triploid and all-female brown trout for aquaculture
}

\author{
Edwige Quillet, L. Foisil, B. Chevassus, Daniel Chourrout, F.G. Liu
}

\section{To cite this version:}

Edwige Quillet, L. Foisil, B. Chevassus, Daniel Chourrout, F.G. Liu. Production of all-triploid and all-female brown trout for aquaculture. Aquatic Living Resources, 1991, 4, pp.27-32. hal-02704075

\section{HAL Id: hal-02704075 \\ https://hal.inrae.fr/hal-02704075}

Submitted on 1 Jun 2020

HAL is a multi-disciplinary open access archive for the deposit and dissemination of scientific research documents, whether they are published or not. The documents may come from teaching and research institutions in France or abroad, or from public or private research centers.
L'archive ouverte pluridisciplinaire HAL, est destinée au dépôt et à la diffusion de documents scientifiques de niveau recherche, publiés ou non, émanant des établissements d'enseignement et de recherche français ou étrangers, des laboratoires publics ou privés. 


\title{
Production of all-triploid and all-female brown trout for aquaculture
}

\author{
Fdwigc Quillet, Iaurc I'oisil, Bernard Chevassus, Danicl Chourrout and F. G. I.iu (1) \\ IVRA, Laboraloire de Génélique des Poissons, 78350 . Jouy-en-Jusas, France. \\ (1) Present address: Aquaculture defarlment, Taiwan Fïsheries Research \\ Institule, Keelung, Taiwan, R.O.C. \\ Received April 24, 1990; accepted October 2, 1990.
}

\begin{abstract}
Heat shocks effective for the production of triploid brown trout (Salmo trutta) werc optimized: $28^{\circ} \mathrm{C}$ shocks lasting 10 to 15 minutes and applicd 5 minutes after fertilization induce very high rates of triploidy (close to $100 \%$ ) without causing much mortality; they can therefore be proposed for mass production of triploid brown trout. Female homogamety in that specics is also demonstrated from analysis of gynogenetic progenies and progenics of sex-inverted females. Although the efficiency of masculinizing hormonal treatments requires further improvement, production of all-female sterile populations is now possible in this species promising for European sea-farming.
\end{abstract}

Quillet E., L. Foisil, B. Chevassus, D. Chourrout, F. G. Liu. Aquat. Lizing Resour., 1991, 4, 27-32.

Keywords : Brown trout, triploidy, gynogenesis, genetic sex-control, masculinization.

Production de populations monosexes femelles et triplö̈des de truite commune pour l'aquaculture.

Résumé

Les paramètres des chocs chauds efficaces pour la production de triploïdes ont été optimisés chez la truite commune (Salmo trutta): des traitements à $28^{\circ} \mathrm{C}$, appliqués 5 minutes après la fécondation et durant 10 à 15 minutes, induisent des taux de triploïdes très élevés (proches de 100\%) sans provoquer de mortalité importante, et peuvent donc êtrc proposés pour unc utilisation à grande échelle. L'homogamétie femelle chez cette espèce est également démontrée par l'étude de descendances gynogénétiques et de descendants d'animaux sexucllement inversés. Bien que l'efficacité des traitements hormonaux d'inversion sexuelle demande à être améliorée, la production de populations monosexes femelles stériles cst désormais possible chez cette espècc prometteuse pour l'aquaculture marine européennc.

Mots-clés : Truite commune, triploïdie, gynogenèse, déterminisme génétique du sexe, inversion sexuelle.

\section{INTRODUCTION}

Up to now, brown trout (Salmo trutta) has mainly been considered as a sport fishing species, but recent investigations have shown that this species might also be a serious candidate for intensive marine aquaculture in Southern European areas: transfer to seawater may be performed at early stages (Quillet et al., 1986), it survives very well in warm highlysalted waters where other species like rainbow trout have poor survival (Quillet et al., 1987), and its growth rate should be competitive with that of Atlantic salmon (Krieg et al,, pers. comm.).

A study of the performances of several wild and domestic stocks in intensive farming conditions (K rieg 
et al., unpubl. data) have shown that a large proportion of fish (mainly males) mature at the age of two in most populations, with considerable negative effects on their further performances. Therefore, the use of sterile stocks will be necessary if this production is to be developed.

In the case of rainbow trout, the production of all female triploid populations was demonstrated to be a very efficient and acceptable tool to produce sterile fish (Chourrout and Quillet, 1982; Lincoln and Scott, 1983; Bye and Lincoln, 1986; Thorgaard, 1983, 1986). In the case of brown trout, very few data are available on this point since the first report of triploidy induction by Scheerer and Thorgaard (1983). Additional data came from attempts to induce triploid hybrids with brown trout as maternal species (Scheerer and Thorgaard, 1983; Scheerer et al., 1987), though these experiments were concerned with the production and the study of hybrids themselves, rather than with the optimization of triploidy yields in pure brown trout species. The work of Arai and Wilkins (1987) and Crozier and Moffet (1989) finally brought complementary information, but they recorded rather low survival rates which are not compatible with a mass production of triploids.

With regard to sex control and production of all female populations in that species, data are, to our knowledge, even more limited, though much has been done in this field with other salmonid species (Jalabert et al., 1975; Johnstone et al., 1978; Donaldson and Hunter, 1982; Yamazaki, 1983; Solar et al., 1984; Cousin-Gerber et al., 1989).

The present article summarizes an optimization of heat treatments inducing all-triploid groups and describes the production of sex-inverted females which, when intercrossed, provide all-female populations of brown trout.

\section{MATERIAI, AND METHODS}

\section{Broodstock}

Brown trout from the INRA domestic strain were kept at the experimental fish farm located at Gournay-sur-Aronde (Oise, France). Rainbow trout males came from the same farm.

\section{Production of sex-inverted females and all-female progenies}

Four experiments were performed from 1982 to 1987 in order to analyze sex determination and to produce sex-inverted females providing viable sperm by methyltestosterone treatment.

In the 1982, 1983 and 1987 experiments, experimental groups were produced by diploid gynogenesis. Activation of the eggs was achieved with rainbow trout sperm previously treated by gamma-rays for the 1982 and 1983 cxperiments (Chourrout et al., 1980) or U.V. rays (Chourrout, 1982) for the 1987 experiment. Diploidization was induced by a heat shock with the parametcrs defined for rainbow trout $\left(26^{\circ} \mathrm{C}\right.$ from 25 to 45 minutes after fertilization, Chourrout and Quillet, 1982).

In the 1986 experiment, experimental groups were produced by a normal fertilization using sperm collected from sex-inverted females resulting from the 1983 experiment.

In all experiments, $17 x$-methyltestosterone was given in the diet from the start of feeding to induce inversion. The hormone was added to the pellets in a solution of ethanol, the final concentration being $3 \mathrm{mg}$ per kilogram of food in all experiments. Treatment duration was 60 to 90 days depending on the experiments. A control group was kept without treatment in cach experiment.

Sex was determined by macroscopical examination of the gonads at six months of age in the untreated groups and by visual determination of mature animals at two and three ycars of age in the treated groups. Mature males wcre classified as functional if they had provided sperm by a gentle abdominal pressure (as ordinary males do).

\section{Induction of triploidy}

Triploidy experiments were performed in 1986 and 1987. Three parameters were tested for the optimization of thermal shocks: time of application after fertilization, temperature and duration; the normal incubation temperature was $10^{\circ} \mathrm{C} \pm 0.5^{\circ} \mathrm{C}$.

A total of seven experiments were carried out (exp. A to G); all were performed with eggs collected from 4 to 10 females.

Three different criteria werc used to evaluate the efficiency of thermal treatments:

In some experiments, the ova were fertilized with rainbow trout irradiated sperm producing pulative gynogenetics: in these cases, the efficiency of the thermal treatment was easily estimated from the hatching rate (all remaining haploid embryos are supposed to die before hatching).

In other experiments, the ova were fertilized with normal rainbow trout sperm, in order to produce diploid hybrids in control, and triploid hybrids in heat-shocked batches. These two hybrids are inviable (Chevassus, 1979; Scheerer and Thorgaard, 1983). In salmonids, triploid hybrids often survive longer than the corresponding diploid hybrids (Chevassus et al., 1983; Scheercr and Thorgaard, 1983; Arai, 1984) and the differential survival at an appropriate time may provide a first estimation of the rate of triploidization without the help of chromosome examination. We actually observed here, by looking at 16 to 18-day-old embryos, a particular occurrence of 
very abnormal embryos (epiboly not completed) in the non-treated batches, which seemed to be replaced by much more normal ones (epiboly completed) in the batches subjected to the heat shocks: the former embryos were supposed to be diploid hybrids, the latter ones being most likely the result of triploidization.

Finally, the ova were fertilized with brown trout sperm in order to produce brown trout triploids. In that case, karyological examinations were required to estimate the rates of triploidy. Slides werc prepared with young embryos, according to the technique of Chourrout and Happe (1986). In these batches, survival at eyed stage, hatching and feeding start were also recorded.

\section{RESULTS}

\section{Production of all female populations}

\section{Efficiency of diploid gynogenesis}

We found that irradiated rainbow trout sperm is able to activate a high proportion of brown trout eggs

Table 1. - Survival rates at day 27 (cyed stage), 52 (end of hatching period) and 90 (start of feeding) in the four groups resulting from fertilization of brown trout cggs by rainbow trout sperm (1982 experiment).

\begin{tabular}{llcccc}
\hline \multirow{2}{*}{ Group } & \multirow{2}{*}{ Sperm } & \multicolumn{2}{c}{$\begin{array}{c}\text { Thermal } \\
\text { shock }\end{array}$} & \multicolumn{3}{c}{ Survival rates (\%) } \\
\hline 1 & Normal & D27 & D52 & D90 \\
\cline { 4 - 6 } 2 & & & 0 & - & - \\
\hline 3 & Irradiated & yes & 19.9 & 0 & - \\
\cline { 3 - 6 } & & no & 63.8 & 0.6 & 0 \\
\hline
\end{tabular}

(tabl. 1). However, viable developments are obtained with non-irradiated sperm. The use of rainbow trout sperm is therefore a convenient tool to prevent the contamination of gynogenetic groups by fish of biparental origin. Additionally, the heat shock used for rainbow trout is efficient enough in brown trout to obtain a satisfactory rate of diploid gynogenetic development.

\section{Sex ratio in gynogenetic groups}

In gynogenetic control groups (not treated with hormone), all animals are females (196 for the 3 experiments) (tabl. 2).

In the same way, all offspring of the sex-inverted females are also females (1986 experiment). These observations provide decisive arguments for a female homogamety in brown trout.
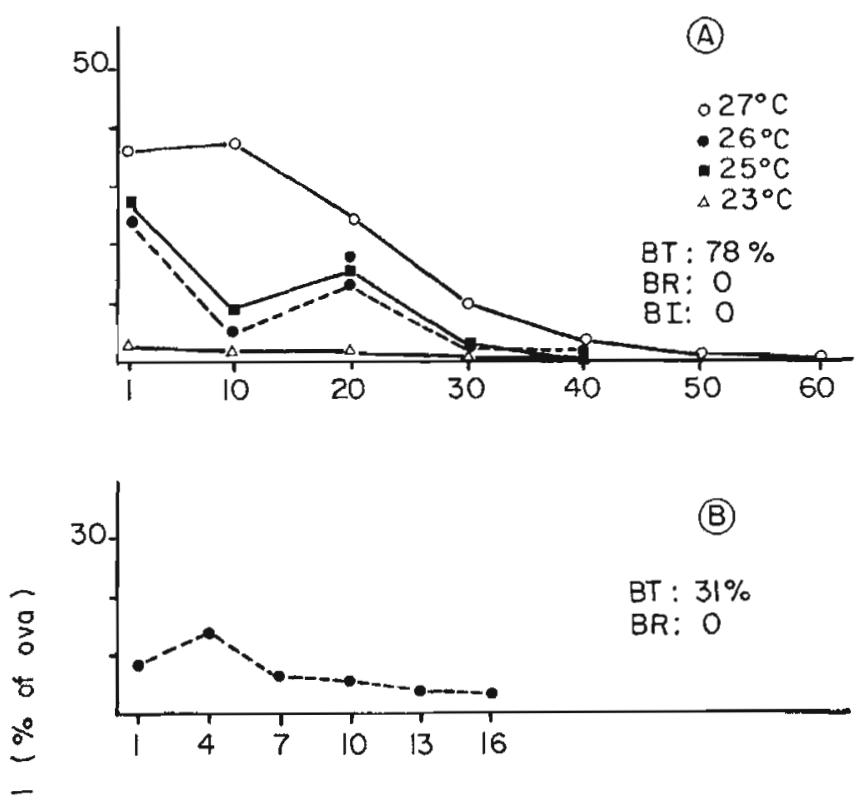

?

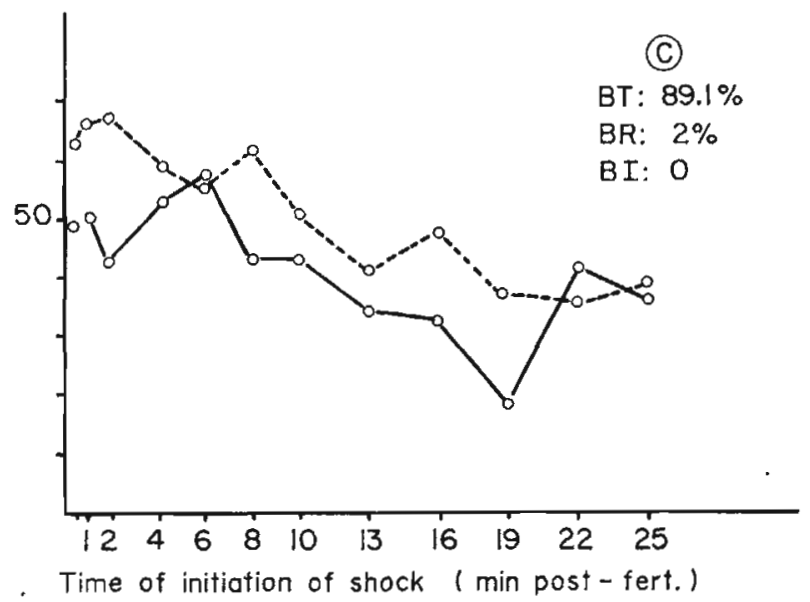

Figure 1. - Effect of the moment of application of 20 min-shocks (in minutes after fertilization) on survival of $q$ brown trout $\times$ o rainbow trout hybrids (continuous lines) and gynogenctic brown trout (dotted lines). BT, BR and BI denote the diploid brown trout control, the untreated diploid hybrid control and the brown trout haploid control respectively. Survival is rccorded: - at day 17 in heat shocked hybrid batches and their BR control in all experiments; - at hatching in heat-shocked gynogenetic batches, BI and BT controls in exp. A and B; - at start of feeding in those same three groups in exp. C.

\section{Efficiency of hormonal treatments}

Treatments by methyltestosterone lead to a variable proportion of mature males at the age of two (31 to $73 \%$ ). In contrast, the frequencies of mature males at this age are systematically high in the standard bisexual populations used for the experiments (about $80 \%$ of the males under the hypothesis of a $1 / 1$ sex ratio). 
Table 2. - Efficiency of the different treatments.

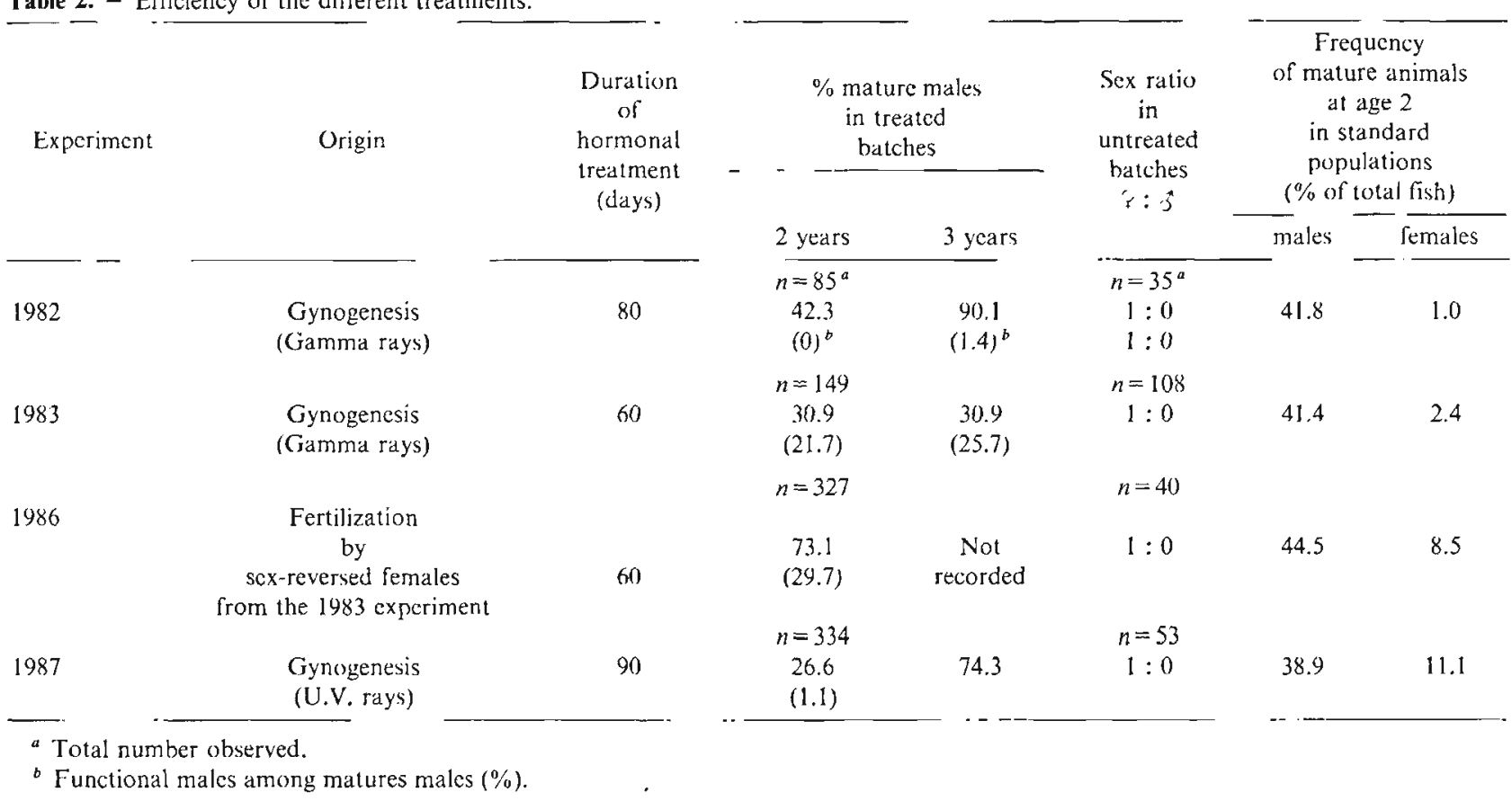

At age 3, two opposite situations are observed:

- for the long treatments ( 80 or 90 days), the remaining immature fish at age two provide a high proportion of late-maturing males; if we consider together age 2 and 3, the efficiency of these masculinizing treatments seems high;

- for the only short treatment (60 days), the immature animals provide mature females only.

The frequency of functional males, which are very rare after long hormonal exposures, increases significantly for shorter ones (60 days); yet most of the males $(71$ to $79 \%$ ) are still not functional in that casc, and can therefore be used practically one time only. No effect of the age on these frequencies can be detected in the different experiments.

\section{Induction of triploidy}

\section{Time of application of heat shock}

Heat shock data from both gynogenetic and hybrid groups are consistent, and show a particular efficiency of the treatments starting within the first seven minutes after fertilization ( fig. 1).

\section{Intensity of heat shock}

Shocks at 25 to $29^{\circ} \mathrm{C}$ were applied for 10 to 30 minutes. For 20 -minute-long shocks, results of $\mathrm{D}$, $\mathrm{E}$ and $\mathrm{G}$ experiments indicate that 26 or $27^{\circ} \mathrm{C}$ provide

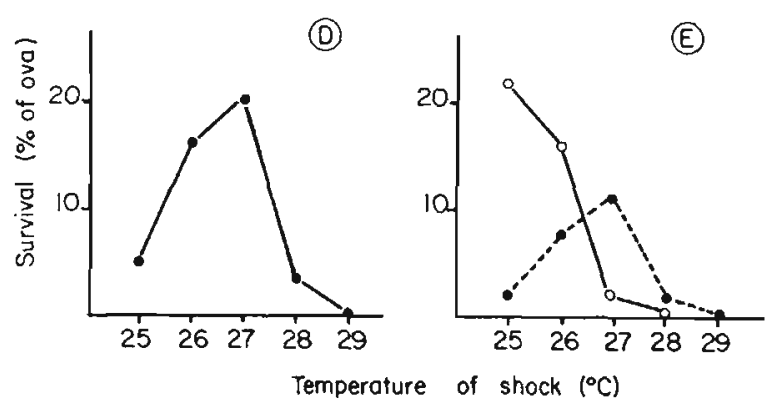

Figure 2. - Effect of temperature of 20 min-shocks applicd 5 minutes after fertilization. Survival is recorded at day 16 in treated hybrid batches (- - ) and their BR control, and at hatching in treated gynogenetic batches (-.-), putative triploid $(\mathrm{O} \longrightarrow$ ) batches, BI and BT controls. Survivals in controls were 75 and $31 \%$ in BT (cxp. D and E respectively), $1 \%$ in BR (exp. D), and $0 \%$ in $\mathrm{BI}$ (exp. $\mathrm{F}$ ).

the higher survival rates (figs. 2 and 3). A statistical analysis of the data of survival in experiment G (which was performed with replications of treatments) leads to the conclusion that better results can be obtained with shorter treatments and/or higher temperatures $\left(27^{\circ} \mathrm{C}\right.$ for 15 minutes or $28^{\circ} \mathrm{C}$ for 10 minutes, which even do not differ from the untreated control; $(a b l .4)$.

Triploidy rates in experiments $F$ and $G$ were estimated by karyological examinations. Embryos displaying 40, 80 and 120 chromosomes were considered haploid, diploid and triploid respectively. 
Expcriment $F$ provided inconsistent results which may be related to the highly variable and usually poor survival rates in the controls: as a matter of fact, the proportion of triploids seems to decrease with the survival ratc of the treated group (tabl. 3).

Table 3. - Survival at hatching and triploidy rate in eight individual females after a 20 minutes shock at $26-26.5^{\circ} \mathrm{C}$ applied 2 minutes after fertilization (cxp. F).

\begin{tabular}{|c|c|c|c|}
\hline \multirow{2}{*}{ Femalc } & \multicolumn{2}{|c|}{ Hatching rate $(\%)$} & \multirow{2}{*}{$\begin{array}{c}\text { Triploids } \\
\text { in treated } \\
\text { batch }\end{array}$} \\
\hline & control & treated & \\
\hline No. 1 & 2 & 0 & \\
\hline No. 2 & 58 & 51 & $30 / 36$ \\
\hline No. 3 & 3 & 0 & \\
\hline No. 4 & 0 & 0 & \\
\hline No. 5 & 67 & 33 & - \\
\hline No. 6 & 67 & 33 & $18 / 30$ \\
\hline No. 7 & 53 & 11 & $6 / 31$ \\
\hline No. 8 & 55 & 0 & - \\
\hline
\end{tabular}

Table 4. - Relative efficiency of different shock intensities in terms of both triploidy rate and survival at fecding start (exp. G).

\begin{tabular}{|c|c|c|c|c|c|c|}
\hline \multirow{2}{*}{$\begin{array}{l}\text { Temperature } \\
\left(^{a}\right) \\
\text { Duration } \\
\text { (min) }\end{array}$} & \multirow[b]{2}{*}{$n$} & \multicolumn{4}{|c|}{ Ploidy level } & \multirow{2}{*}{$\begin{array}{c}\text { Triploidy } \\
(\%)\end{array}$} \\
\hline & & $2 n$ & $3 n$ & $3 n$ & $\begin{array}{c}\text { Total } \\
\text { observed }\end{array}$ & \\
\hline $26 / 20$ & 0 & 2 & 1 & 15 & 18 & 83.3 \\
\hline $26 / 25$ & 1 & 1 & 3 & 15 & 20 & 75.0 \\
\hline $26 / 30$ & 1 & 3 & 0 & 15 & 19 & 78.9 \\
\hline $27 / 15$ & 0 & 3 & 1 & 15 & 19 & 78.9 \\
\hline $27 / 20$ & 0 & 5 & 0 & 12 & 17 & 70.6 \\
\hline $27 / 25$ & 1 & 3 & 0 & 15 & 19 & 78.9 \\
\hline $28 / 10$ & 0 & 1 & 0 & 18 & 19 & 94.7 \\
\hline $28 / 15$ & 0 & 1 & 0 & 17 & 18 & 94.4 \\
\hline $28 / 20$ & 0 & 0 & 3 & 16 & 19 & 84.2 \\
\hline Untreated control & 0 & 20 & 0 & 0 & 20 & - \\
\hline
\end{tabular}

Ranking of treatments for survival ${ }^{a}$

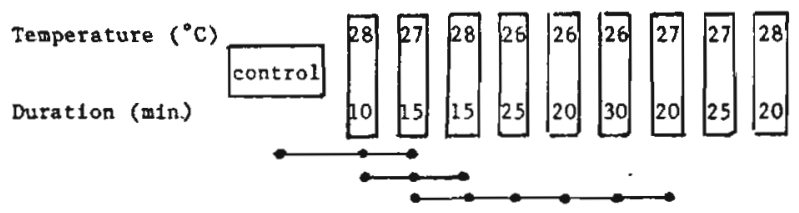

a Multiple comparison performed with $t$-test performed on arcsinus transformed date. - - : treatments not significantly different.

On the other hand, very high rates of triploidy were obtained in experiment $\mathrm{G}$ with $28^{\circ} \mathrm{C}$ shocks lasting 15 minutes or less (tabl. 4). Shocks at $28^{\circ} \mathrm{C}$ applied 5 minutes after fertilization for 10 minutes were particularly efficient for inducing triploidy with satisfactory survival rates.

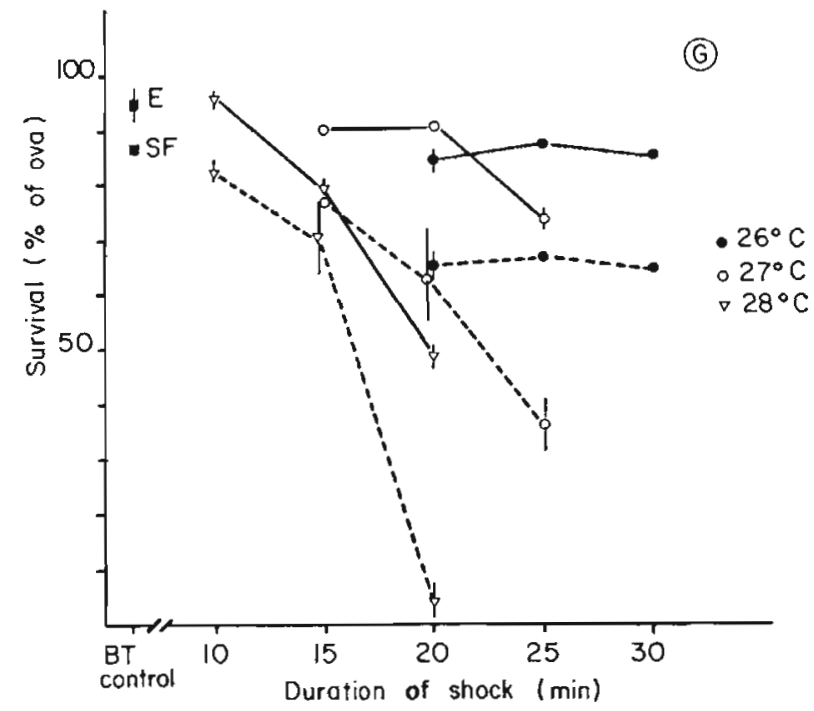

Figure 3. - Effect of shock intensity on survival in triploid groups (shocks are applicd 5 minutes after fertilization). Reported values are the mean of replicates, lips of vertical bars indicate values of each replicate. Survivals are recorded at eyed stage (E, continuous lines) and start of feeding (SF, dotted lines).

\section{DISCUSSION AND CONCLUSION}

The present study shows that the mass production of triploid brown trout is feasible: heat shocks are identified, that induce very high rates of triploidy (close to $100 \%$ ) without major reduction of survival. In contrast, Arai and Wilkins (1987) recorded 33\% average hatching rates in the batches containing more than $80 \%$ triploids despite very good hatching rates in the controls (more than 96.7\%).

This study also confirms that sex determination in brown trout is based on female homogamety; this is also the case for all the other salmonids examined up to now (see Chourrout, 1988 for a review).

Dietary administration of methyltestosterone ( $3 \mathrm{mg} / \mathrm{kg}$ of food) for 80 to 90 days from feeding start has efficiently resulted in sex-inverted females. The late maturation of part of this group of animals can be explained by different factors, the effect of which cannot be measured separately in our studies: (1) an effect of gynogenesis on the age at sexual maturation. However, this has not been observed in one of our experiments performed on the rainbow trout (unpubl. data); (2) the fact that the treated animals are genetic females: indeed, a very low proportion of females become mature at age two in brown trout (see tabl. 2); (3) an effect of the methyltestosterone treatments on the age of maturation. Such an effect has not been observed in rainbow trout (Cousin-Gerber et al., 1989) but cannot be excluded in brown trout without specific experiments. 
The frequencies of functional males are rather low especially for long hormonal treatments. The recent study by Cousin-Gerber et al. (1989) in rainbow trout has demonstrated that a reduction of both concentration of hormone and duration of trcatment greatly enhances this parameter, while the total percentage of sex-inverted animals remains unaffected (always more than $90 \%$ in their experiment); at similar approach should be developed in brown trout.
Nevertheless, techniques to produce all-female triploid brown trout are now available.

Further analysis of their breeding performances will have to be undertaken before conclusions can be drawn about their interest for aquaculture; indeed, previous studies on other salmonids have demonstrated that triploidy may have some negative effects on survival or/and growth (see Quillet et al., 1987 and 1988 for a review).

\section{Acknowledgements}

Part of this study was supported by an IFREMER grant in 1986 (Rer. 1210628Y).

\section{REFERENCES}

Arai K., 1984. Developmental genetic studies on salmonids: morphogenesis, isozyme phenotype and chromosomes in hybrid embryos. Reprinted from memoirs of the Faculty of Fisherics, Hokkaido University, 31, 1-94.

Arai K., N. P. Wilkins, 1987. Triploidization of brown trout (Salmo trulla) by heat shocks. Aquaculture, 64, 97-103.

Bye V. I., R. Lincoln, 1986. Commercial methods for the control of sexual maturation in rainbow trout (Sulmo) gairdneri R.). Aquaculture, 57, 299-309.

Chevassus B., 1979. Hybridization in salmonids: results and perspectives. Aquaculture, 17, 113-128.

Chevassus B., R. Guyomard, D. Chourrout, E. Quillet, 1983. Production of viable hybrids in salmonids by triploidisation. Génét. Sél. Evol., 15, 519-532.

Chourrout D., B. Chevassus, F. Herioux, 1980. Analysis of an Hertwig effect in the rainbow trout (Salmo gairdneri R.) after fertilization with irradiated sperm. Reprod. Nutr. Dev., 20, 719-726.

Chourrout D., 1982. Gynogenesis caused by ultraviolet irradiation of salmonid sperm. J. Exp. Zool., 223, 175-181.

Chourrout D., E. Quillet, 1982. Induced gynogenesis in the rainbow trout: scx and survival of progenics. Production of all-triploid populations. Theor. Appl. Genet., 63, 201-205.

Chourrout D., 1988. Revuc sur le déterminisme génćtique du sexe des poissons téléostéens. Bull. Soc. Zool. Fr., 113 , 123-144.

Chourrout D., A. Happe, 1986. Improved methods of direct chromosome preparation in rainbow trout, Salmo gairdneri. Aquaculture, 52, 255-261.

Crozier W. W., I. J. J. Moffetl, 1989. Experimental production of triploid brown trout (Salmo trutta L.) using heat shock. Aquacult. Fish. Manage., 20, 343-353.

Donaldson E. M., G. A. Hunter, 1982. Sex control in fish with particular reference to salmonids. Can. J. Fish. Aquat. Sci., 39, 99-110.

Jalabert B., R. Billard, B. Chevassus, 1975. Preliminary experiments on scx control in trout: production of sterile fishes and simultaneous self fertilizable hermaphrodites. Ann. Biol. Anim. Biochem., 15. 19-28.
Johnstone R., T. H. Simpson, A. F. Youngson, 1978. Sex reversal in salmonid culture. Aquaculture, 13, 115-134.

I.jncoln R. F., A. P. Scott, 1983. Production of all-female triploid rainbow trout. Aquaculture, 30, 375-380.

Cousin-Gerber M., C;. Burger, C. Boísseau, B. Chevassus, 1989. Effect of methyltestosterone on sex differentiation and gonad morphogenesis in rainbow trout Oncorhynehus mykiss. Aquat. Living Resour., 2, 225-230.

Quillet E., F. Krieg, A. Happe, B. Chevassus, 1986. Etude des possibilités de transfert automnal en mer de juvéniles de truite fario (Salmo trutta). Bull. Fr. Pêche Piscic'., $303,125-133$.

Quillet E., B. Chevassus, F. Krieg, 1987. Characterization of auto and allotriploid salmonids for rearing in seawater cages. In: Proc. World Symp. on Selection, Hybridization, and Genetic Engincering in Aquaculture, Bordeaux, France, 27-30 May, K. Tiews ed., Vol. II. Bcrlin, 239-252.

Quillet E., B. Chevassus, J. M. Blanc, F. Krieg, D. Chourrout, 1988. Performances of auto and allotriploids in salmonids. I - Survival and growth in freshwater farming. Aquat. Living. Resour., 1, 29-43.

Scheerer P. D., G. H. Thorgaard, 1983. Increascd survival in salmonid hybrids by induced triploidy. Can. J. Fish. Aquat. Sci., 40, 2040-2044.

Scheerer P. D., G. H. Thorgaard, J. E. Seeb, 1987. Pcrformance and developmental stability of triploid tiger trout (Brown trout $; \times$ Brook trout 3 ). Trans. Am. Fish. Sinc., $116,92-97$.

Solar J. I., E. M. Donaldson, G. A. Hunter, 1984. Optimization of treatment regimes for controlled sex differenciation and sterilization in wild rainbow trout (Salmo) gairdneri R.) by oral administration of $17 \mathrm{x}$-mcthyltestosteronc. Aquaculture, 42, 129-139.

Thorgaard G. H., 1983. Chromosome set manipulation and sex control in fish. In: Fish Physiology, Academic Press, New York, Vol. 4, Part B, 405-434.

Thorgaard G. H., 1986. Ploidy manipulation and performance. Aquaculture, 57, 57-64.

Yamazaki F., 1983. Sex control and manipulation in fish. Aquaculture, 33, 329-354. 